\title{
TGF- $\beta 1$ System in Leydig Cells. Part II: TGF- $\beta 1$ and Progesterone, Through Smad1/5, are Involved in the Hyperplasia/hypertrophy of Leydig Cells
}

\author{
Candela R. GONZALEZ ${ }^{1)}$, Betina GONZALEZ ${ }^{1)}$, Susana B. RULlI ${ }^{1)}$, Mara L. dos SANTOS ${ }^{2)}$, \\ Guilherme MATTOS JARDIM COSTA ${ }^{2)}$, Luiz R. FRANÇA ${ }^{2)}$, Ricardo S. CALANDRA ${ }^{1)}$ and \\ Silvia I. GONZALEZ-CALVAR ${ }^{1,3)}$

\begin{abstract}
1) Instituto de Biologíia y Medicina Experimental, CP1428 Buenos Aires, Argentina, ${ }^{2)}$ Laboratory of Cellular Biology, Department of Morphology, Federal University of Minas Gerais, Minas Gerais 31270-901, Brazil and ${ }^{3)}$ Facultad de Medicina, Universidad de Buenos Aires, CP 1121 Buenos Aires, Argentina
\end{abstract}

\begin{abstract}
Several reports indicate that transforming growth factor $\beta 1$ (TGF- $\beta 1$ ) participates in the regulation of cell cycle progression. In this work, we analyzed the in vitro effect of TGF- $\beta 1$ on Leydig cell proliferation markers and the in vivo effect of this cytokine in Leydig cell hyperplasia/hypertrophy. The in vitro effect of TGF- $\beta 1$ (1 ng/ml) plus progesterone $\left(10^{-6} \mathrm{M}\right)$ on purified Leydig cells from 3 week-old mice increased the immunocytochemically detected PCNA and stimulated the phosphorylation of Smad 1/5. Progesterone $\left(10^{-6} \mathrm{M}\right)$ in the presence or absence of TGF- $\beta 1$ diminished the ratio $\mathrm{Bax} / \mathrm{Bcl}$-2. Morphometric testicular studies of mice treated with progesterone (s.c.) plus TGF- $\beta 1$ (intratesticular), showed an increase in interstitial volume and a decrease in tubular volume. Furthermore, the cytoplasmic volume of Leydig cells showed an increment in this experimental group with a diminution in nuclear volume. Thus, it turned out that the administration of progesterone and TGF- $\beta 1$ augmented the volume of Leydig cells. These results indicate a clear effect of TGF- $\beta 1$ in the hypertrophy/hyperplasia of Leydig cells.
\end{abstract}

Key words: Leydig, Proliferation markers, TGF- $\beta 1$

(J. Reprod. Dev. 56: 400-404, 2010)

$\mathbf{T}$ GF- $\beta$ influences steroidogenesis [1] and also modulates Leydig cell DNA synthesis by regulating Leydig cell proliferation [2]. Moreover, either the absence or overexpression of this factor affects male reproductive function, supporting the participation of TGF- $\beta$ signaling pathways in the orchestration of testicular development and spermatogenesis [3-5]. The effect of TGF- $\beta 1$ is exerted via specific type I and II serine/threonine kinase receptors. Type II receptor (TGF- $\beta$ RII) transphosphorylates and activates type I receptor (TGF- $\beta \mathrm{RI}$ ), which in turn phosphorylates and activates downstream nuclear effectors, named Smads [6]. It has been described that TGF- $\beta 1$ activates two distinct type I receptors activin receptor-like kinase 1 (ALK1), which promotes Smad 1/5 phosphorylation, and ALK5, which induces Smad 2/3 phosphorylation. In endothelial cells, endoglin blocks TGF- $\beta$-induced growth arrest by promoting ALK-1 signaling, and indirectly reduces ALK5 signaling leading to cell proliferation [7].

It has been shown that TGF- $\beta$ and its receptors are altered in pathological conditions such as cancer and hyperplasia of different tissues [8]. Rulli et al. [9] have reported that transgenic male mice overexpressing $\alpha$ and $\beta$ subunits of hCG (hCG+ mice) are infertile and that their reproductive organs show severe alterations. In addition, testicular steroidogenesis is enhanced, showing high levels of circulating testosterone and progesterone. A remarkable feature of

Received: September 25, 2009

Accepted: March 30, 2010

Published online in J-STAGE: April 22, 2010

(C)2010 by the Society for Reproduction and Development

Correspondence: SI Gonzalez-Calvar (e-mail: scalvar@dna.uba.ar.) these animals is that chronic hCG hyperstimulation leads to Leydig cell hyperplasia/hypertrophy in prepubertal mice, which diminishes in adulthood $[9,10]$.

With the aim to analyze the participation of the TGF- $\beta 1$ system in hyperplasia/hypertrophy of Leydig cells, we evaluated the following things in 3-week-old mice of the FBV/n strain: 1) the in vitro effect of TGF- $\beta 1$ and progesterone on proliferation markers (Proliferating Cell Nuclear Antigen (PCNA) and Bax/Bcl-2 ratio) and Smad 1/5 activation in purified Leydig cells; and 2) the in vivo effect of TGF- $\beta 1$ and progesterone on Leydig cell morphometric assessment.

\section{Materials and Methods}

Animals

Male mice ( 3 weeks of age) of the FVB/n strain were bred in our Animal Care Unit (Animal Care Laboratory, Instituto de Biología y Medicina Experimental - Consejo Nacional de Investigaciones Científicas y Técnicas, Buenos Aires). They were kept under controlled temperature (23 C) and lighting conditions (12 h-dark/light cycles). Tap water and commercial mouse chow were provided ad libitum. All animal studies were conducted according to protocols for animal use, approved by the Institutional Animal Care and Use Committee (Instituto de Biología y Medicina Experimental - Consejo Nacional de Investigaciones Científicas y Técnicas) following the National Institute of Health (USA) guidelines. Male mice were euthanized by asphyxiation with carbon dioxide $\left(\mathrm{CO}_{2}\right)$, and testes were rapidly removed and immediately used for isolation of Leydig 
cells or fixed for immunohistochemistry.

\section{Preparation of purified mouse Leydig cells}

Leydig cells were isolated from testes of mice at 3 weeks of age using a previously described [11] procedure that was adapted and validated to the mouse. The right and left testes of each animal were decapsulated, pooled, immersed in Medium 199 containing $0.1 \%$ bovine serum albumin (BSA; Sigma) and $0.2 \mathrm{mg} / \mathrm{g}$ tissue collagenase (Sigma Aldrich), at $\mathrm{pH} 7.2$, and incubated for $10 \mathrm{~min}$ at 32-34 C with gentle shaking. The incubation was stopped by adding $50 \mathrm{ml}$ of cold Medium 199 without collagenase. The supernatants were filtered (cell strainer; Becton Dickinson and Company, $70 \mu \mathrm{m}$ ) and centrifuged at $800 \mathrm{~g}$ for $10 \mathrm{~min}$. Deoxyribonuclease was added $(1.25 \mathrm{mg} \mathrm{m} / \mathrm{l})$. The pellet was resuspended and applied to a discontinuous Percoll density gradient and centrifuged (30 min, $1600 \mathrm{~g}$ ). Cells that migrated to the $1.06-1.12 \mathrm{~g} / \mathrm{ml}$ density fraction were collected and washed with Medium 199. An aliquot was incubated with $0.4 \mathrm{mg} / \mathrm{ml}$ trypan blue and used for cell counting and viability assay using a light microscope. The viability of the Leydig cell preparations (Trypan Blue staining) was 95\%. To evaluate enrichment in Leydig cells, the activity of $3 \beta$-hydroxysteroid dehydrogenase ( $3 \beta$-HSD) was measured as previously described by Levy et al. [12]. Cell preparations were 85-90\% enriched with mouse Leydig cells.

\section{In vitro incubations of purified Leydig cells}

Aliquots ( $1 \mathrm{ml}$ ) of cell suspension in Medium 199 containing $10^{6}$ mouse Leydig cells were incubated in either the presence or absence of TGF- $\beta 1(1 \mathrm{ng} / \mathrm{ml})$, progesterone $\left(10^{-6} \mathrm{M}\right)$ or progesterone $\left(10^{-6} \mathrm{M}\right)+$ TGF- $\beta 1(1 \mathrm{ng} / \mathrm{ml})$ for $4 \mathrm{~h}$ at $37 \mathrm{C}$ under a humid atmosphere of $5 \% \mathrm{CO}_{2} / 95 \%$ air. Then, the media were removed, and cells were harvested and kept at $-80 \mathrm{C}$ for RNA extraction.

To evaluate PCNA expression $300 \mu$ l of cell suspension in Medium 199 containing $10^{5}$ Leydig cells were incubated with progesterone $\left(10^{-6} \mathrm{M}\right)$ for $3 \mathrm{~h}$ and then stimulated with TGF- $\beta 1$ (1 $\mathrm{ng} / \mathrm{ml}$ ) for 1 hour in 8-well chambers (LabTek, Nunc) at $37 \mathrm{C}$ under a humid atmosphere of $5 \% \mathrm{CO}_{2} / 95 \%$ air. The media were then removed, and the cells were fixed in paraformaldehyde (4\%) and dehydrated with $70-100 \%$ ethanol. The cells were used for immunocytochemical studies.

\section{RNA isolation and semi quantitative RT-PCR}

Total RNA from purified Leydig cells was extracted with an RNAeasy kit (Qiagen), according to the manufacturer's instructions. Total RNA $(0.4 \mu \mathrm{g})$ was used for reverse transcription with MMLV reverse transcriptase (Promega). Reverse-transcribed cDNAs $(5 \mu \mathrm{l})$ were used to amplify mRNA sequences by a PCR reaction with Go-TaqDNA polymerase (Promega) and the following specific forward ( $F$ ) and reverse ( $R$ ) primers: 5, ACACCTGAGCTGACCTTG 3', F, and 5' CGCTCACGGAGGAAGTC 3', R for Bax and 5' CTGCAGAACCTCCCTGTG 3', F, and 5' CGCCGGGCTTCTTCTTC 3', R, for Bcl-2. The first denaturation was performed for $4 \mathrm{~min}$ at $94 \mathrm{C}$. The successive denaturation steps were performed for $1 \mathrm{~min}$ at $94 \mathrm{C}$ followed by annealing at a specific temperature (55 $\mathrm{C}$ for both primers) for 1 min and extension at $72 \mathrm{C}$ for $90 \mathrm{sec}$. Thirty cycles were used for each pair of primers. A final elongation for $7 \mathrm{~min}$ at $72 \mathrm{C}$ was used to amplify transcripts. The housekeeping gene used was $\beta$-actin (25 cycles). The amplified cDNA fragments were size-fractionated in $2 \%$ agarose gel and visualized by staining with ethidium bromide. The intensity of bands obtained by electrophoresis was evaluated using the Scion Image for Windows software. Results are expressed as the ratio between the expression of the specific gene and $\beta$-actin.

\section{Immunocytochemical studies}

Cells fixed in an 8-well chamber were washed with ethanol (100-70\%) and then washed with PBS. Endogenous peroxidase activity was inhibited with $0.5 \% \mathrm{v} / \mathrm{v} \mathrm{H}_{2} \mathrm{O}_{2}$ in methanol for $20 \mathrm{~min}$ at room temperature. Then, the cells were subjected to saponin (5 $\mathrm{mg} / \mathrm{ml}, 5 \mathrm{~min})$ and proteinase $\mathrm{K}(20 \mu \mathrm{g} / \mathrm{ml}, 90 \mathrm{sec})$ treatment for antigenic recovery. The cells were blocked for $1 \mathrm{~h}$ with $10 \% \mathrm{v} / \mathrm{v}$ normal goat serum in PBS- 1\% BSA and then incubated overnight at $4 \mathrm{C}$ with primary antibody (anti-PCNA, sc-56, Santa Cruz; $1: 100)$.

After five rinses in PBS, the cells were incubated for $1 \mathrm{~h}$ at RT with biotinylated secondary antibody (Vector Labs, 1:1000). After further washing in PBS, the cells were incubated for $1 \mathrm{~h}$ with streptavidin-peroxidase complex diluted 1:100 (ABC kit, Vector Labs). They were then washed twice with PBS, and development of peroxidase activity was performed with $0.05 \%$ w/v 3,3'-diaminobenzidine and $0.1 \% \mathrm{v} / \mathrm{v}_{2} \mathrm{O}_{2}$ in Tris- $\mathrm{HCl}$; they were subsequently subjected to a final wash with distilled water. Negative controls were processed simultaneously by omitting the primary antibodies.

\section{Immunoblotting}

Approximately, $2 \times 10^{6}$ mouse Leydig cells were homogenized in $20 \mathrm{mM}$ Tris- $\mathrm{HCl}$ (pH 8), $137 \mathrm{mM} \mathrm{NaCl}$ buffer containing 10\% glycerol, 1\% lysis buffer (IGEPAL CA-630, Sigma) and 1\% of a preformed mixture of protease inhibitors (Sigma). Samples were heated at $95 \mathrm{C}$ for $5 \mathrm{~min}$ under reducing conditions (10\% mercaptoethanol). Homogenates (220 $\mu$ g protein) were loaded onto tricineSDS-polyacrylamide gels (10\%), electrophoretically separated and blotted onto nitrocellulose. Protein concentrations were measured by the method of Lowry et al. [13]. Blots were incubated with rabbit polyclonal anti-Smad 1/5/8 (N-18)-R (sc-6031-R, Santa Cruz Biotechnology, 1:200) or rabbit polyclonal anti-p-Smad 1/5/8 (\#9511, Cell Signaling Technology, Beverly, MA, USA; 1:200), and subsequently with the peroxidase-labeled secondary antibody goat anti-rabbit IgG (1:5000, Sigma). Signals were detected with an ECL kit (Amersham Pharmacia Biotech AB). The intensity of bands obtained by electrophoresis was evaluated using the Scion Image for Windows software.

\section{Testis morphometry}

To study testicular morphometry, mice were injected with progesterone (s.c. $20 \mathrm{mg} / \mathrm{Kg}$ ) or castor oil at 3 weeks of age. After $24 \mathrm{~h}$, the animals received an intratesticular injection of TGF- $\beta 1$ (1 $\mu \mathrm{l}, 1,5 \mathrm{ng} / 100 \mu \mathrm{l})$. Control animals were injected with $1 \mu \mathrm{l}$ of saline. The animals were euthanized $24 \mathrm{~h}$ later.

Testes were immersed in $4 \%$ buffered glutaraldehyde for $48 \mathrm{~h}$ 
and then washed with $0.5 \mathrm{M}$ phosphate buffer. Tissues were embedded in glycol methacrylate, and subsequently, sections $4 \mu \mathrm{m}$ in thick were obtained and stained with toluidine blue.

The volume densities of the testicular tissue components were determined by light microscopy using a 441-intersection grid placed in the 10× ocular of a light microscope [14]. Fifteen fields chosen randomly (6615 points) were scored for each animal at $400 \times$ magnification. Artifacts were rarely seen and were not considered in the total number of points utilized to obtain volume densities. Points were classified as one of the following: seminiferous tubule, comprising tunica propria, epithelium and lumen; Leydig cells; blood vessels and lymphatic spaces; or connective tissue. The volume of the each component of the testis was determined as the product of the volume density and testis volume.

The individual volume of Leydig cells was obtained from their nuclear volume and the proportion of the nucleus and cytoplasm. To calculate the proportion of the nucleus and cytoplasm, a 441point square lattice was placed over the sectioned material at $1000 \times$ magnification. One thousand points over the Leydig cells were counted for each animal. The Leydig cell nuclear volume was expressed in $\mu \mathrm{m}^{3}$ and obtained by the formula $4 / 3 \pi \mathrm{r}^{3}$, where $\mathrm{r}=$ nuclear diameter/2. The number of Leydig cells per testis was estimated from the Leydig cell individual volume and the volume occupied by Leydig cells in the testis parenchyma [14].

\section{Statistical analysis}

Mean and standard error (SEM) were calculated. GraphPad Prism (version 3.00 for Windows, GraphPad software, San Diego, CA, USA) was used for one-way analysis of variance. Tukey's $t$ test and the Student's $t$-test were used when differences between two or more than two groups were compared, respectively. A Pvalue of less than 0.05 was considered significant.

\section{Results}

\section{Effect of TGF- $\beta 1$ and progesterone on proliferation markers in Leydig cells \\ Incubation of purified Leydig cells from 3-week-old mice with} progesterone $\left(10^{-6} \mathrm{M}\right)$ did not induce PCNA expression (Fig 1, panel B). However, the incubation with TGF- $\beta 1$ (1 ng/ml) showed a slight increase in the induction of this proliferation marker (Fig 1, panel C). Moreover, the incubation with TGF- $\beta 1(1 \mathrm{ng} / \mathrm{ml})$ plus progesterone $\left(10^{-6} \mathrm{M}\right)$ clearly increased PCNA expression with respect to the control (Fig 1, panels $\mathrm{D}$ and $\mathrm{A}$, respectively).

Furthermore, purified Leydig cells were incubated with TGF- $\beta 1$ $(1 \mathrm{ng} / \mathrm{ml})$ and progesterone $\left(10^{-6} \mathrm{M}\right)$, and the gene expression of $\mathrm{Bax}$ and $\mathrm{Bcl}-2$ was analyzed by RT-PCR. Fig. 1 (panel E) shows that progesterone in the presence or absence of TGF- $\beta 1$ decreased the ratio of $\mathrm{Bax} / \mathrm{Bcl}-2$, which reflects the apoptotic index, provided that Bax gene expression diminished without changes in $B c l-2$ gene expression.

\section{Effect of TGF- $\beta 1$ and progesterone on $p$-Smad 1/5}

In order to study the molecular events involved in the TGF- $\beta 1$ transduction pathway, we investigated the protein expression of Smad $1 / 5$, which is activated by phosphorylation and is involved in
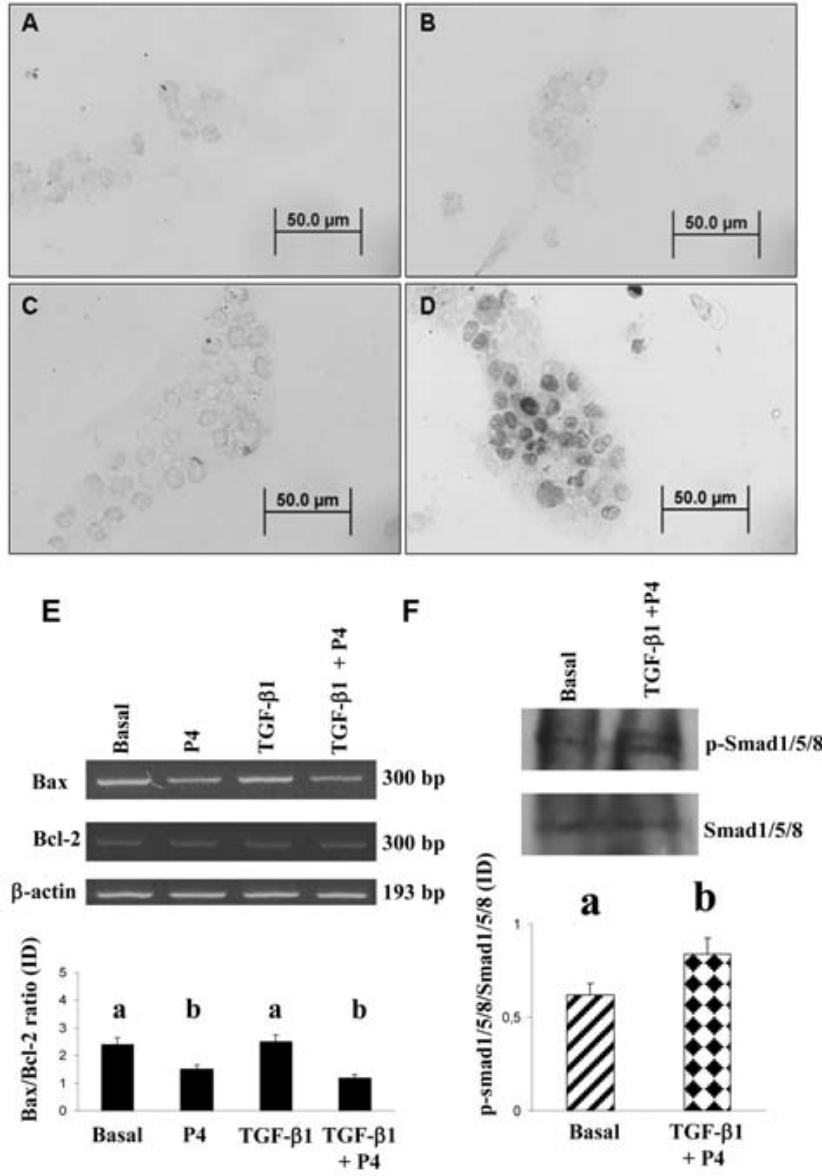

Fig. 1. Effect of progesterone and TGF- $\beta 1$ on PCNA expression. Purified Leydig cells from mice at 3 weeks of age were incubated under basal conditions (panel A) or stimulated with progesterone $\left(10^{-6} \mathrm{M}\right.$; panel B), TGF- $\beta 1$ ( $1 \mathrm{ng} / \mathrm{ml}$; panel C) or progesterone + TGF- $\beta 1$ (panel D). PCNA was revealed by immunocytochemical detection. Effect of progesterone and TGF- $\beta 1$ on Bax and Bcl-2 gene expression (panel E). Purified Leydig cells from mice at 3 weeks of age were incubated under basal conditions or stimulated with progesterone $\left(10^{-6} \mathrm{M}\right)$, TGF$\beta 1(1 \mathrm{ng} / \mathrm{ml})$ or progesterone + TGF- $\beta 1$. Bax and Bcl-2 were evaluated by semiquantitative PCR reaction. Results are represented with an arbitrary scale and expressed as the ratio between the expressions of $\mathrm{Bax}, \mathrm{Bcl}-2$ and $\beta$-actin (integrated density, ID). Data are plotted as the mean ID \pm SEM $(n=5)$ of one experiment out of three. Effect of progesterone and TGF- $\beta 1$ on p-Smad 1/5/8 expression (panel F). Purified Leydig cells from mice at 3 weeks of age were incubated under basal conditions or stimulated with progesterone $\left(10^{-6} \mathrm{M}\right)+$ TGF- $\beta 1$ ( $1 \mathrm{ng} / \mathrm{ml}$ ). Smad 1/5/8 and p-Smad 1/5/8 were evaluated by Western blot. Results for the lower band are represented with an arbitrary scale and expressed as the ratio between the expression of p-Smad 1/5/8 and Smad 1/5/8 (integrated density, ID). Data are plotted as the mean ID \pm SEM $(n=5)$ of one experiment out of three.

proliferation events triggered by this cytokine. TGF- $\beta 1(1 \mathrm{ng} / \mathrm{ml})$ in the presence of progesterone $\left(10^{-6} \mathrm{M}\right)$ increased the expression of p-Smad 1/5 (Fig. 1, panel F). A doublet of bands was observed in the TGF- $\beta 1$ plus progesterone incubates, whith the upper band 
A

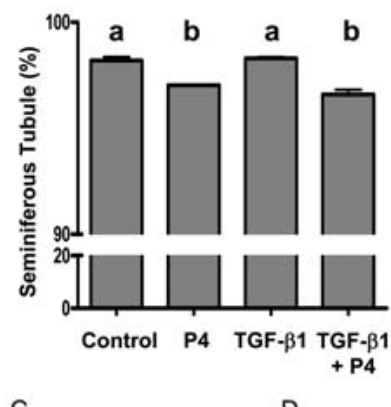

C
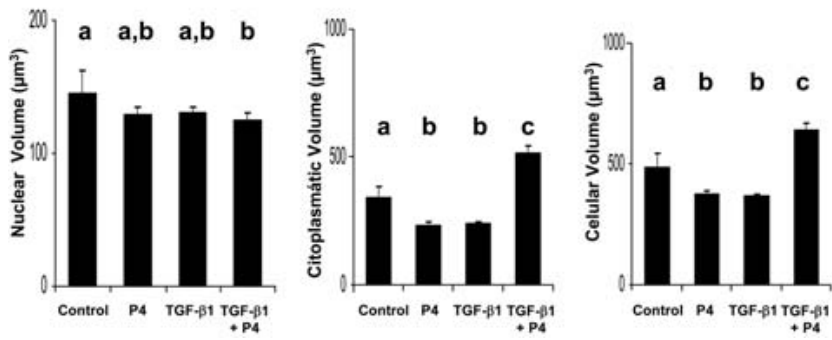

Fig. 2. Volume densities of the testicular tissue (panels A and B) and morphometric data of Leydig cells (panels C, D and E) of mice at 3 weeks of age. Animals were injected with progesterone (s.c. $20 \mathrm{mg} / \mathrm{Kg}$ ) or castor oil. After $24 \mathrm{~h}$, the animals received an intratesticular injection of TGF- $\beta 1(1 \mu \mathrm{l}, 1.5 \mathrm{ng} / 100 \mu \mathrm{l})$. The mice were euthanized $24 \mathrm{~h}$ later. Data are plotted as the mean ID $\pm \operatorname{SEM}(\mathrm{n}=5)$

only present in these incubates and the lower band observed also under the basal conditions but with lower intensity.

\section{Testis morphometry}

The volume of seminiferous tubule (\%) decreased and that of the interstitium (\%) increased in animals treated with progesterone plus TGF- $\beta 1$ and progesterone with respect to the control group (Fig 2; panels $\mathrm{A}$ and $\mathrm{B}$, respectively). In spite of showing a slight increase in Leydig cell number in the TGF- $\beta 1$ and progesterone experimental group, there were no significant differences between groups (data not shown). However, in the mice treated with TGF- $\beta 1$ plus progesterone, the nuclear volume decreased and the cytoplasmic volume increased in Leydig cells respect to the control group (Fig. 2, panels C and D, respectively). Thus, Leydig cell volume was significantly increased in this experimental group (Fig. 2, panel E).

\section{Discussion}

One of the most important functions of TGF- $\beta 1$ is regulation of cell cycle progression. Different observations have been made about this effect. It has been described that TGF- $\beta 1$ stimulates apoptosis of endothelial, epithelial, fibroblastic and hematopoietic cells, but at the same time, is capable of promoting proliferation in epithelial and endothelial cells [15]. This dual effect on cell proliferation has been extensively described in endothelial cells, where high doses of TGF- $\beta 1$ inhibit cell cycle progression and low doses of this cytokine exert the opposite effect $[7,16]$.

It might be possible that increased levels of endogenous TGF- $\beta 1$ caused by some pathological conditions besides proliferation of Leydig cells trigger the Leydig cell hyperplasia / hypertrophy. Thus, the present study would provide the basic molecular information for understanding this particular testicular pathogenesis.

Immunocytochemical studies on purified Leydig cells incubated with low concentrations of TGF- $\beta 1$ plus progesterone showed a clear increase in PCNA expression, while TGF- $\beta 1$ alone had a slight effect on this proliferation marker. Progesterone alone did not modify PCNA immunodetection; however, it has been observed that progesterone stimulates endoglin gene expression in mouse Leydig cells [17]. Moreover, incubation of Leydig cells with TGF- $\beta 1$ and progesterone diminished the expression of Bax (pro-apoptotic gene) without any modification of $\mathrm{BCl}$-2 (anti apoptotic gene) expression, causing a lower $\mathrm{Bax} / \mathrm{Bcl}-2$ ratio compared with the control treatments.

Furthermore, we observed a clear increase in Smad1/5 phosphorylation in Leydig cells treated with TGF- $\beta 1$ plus progesterone. A doublet of bands was observed in the western blot detection of phospho-Smad 1/5/8. In this context, some authors have also observed multiple bands in western blot detection of this protein $[18,19]$. Daly et al. [18] identified these bands by a siRNA knockdown of all the individual Smad proteins and established that the upper band is comprised mainly of Smad1, with some Smad5, whereas the lower band is an isoform of Smad5.

The results of the present study are in agreement with those of Lebrin et al. [20] and Goumans et al. [21]. These authors pointed out that a low dose of TGF- $\beta 1$, via the ALK1/Smad1/5 signaling pathway, leads to epithelial cell proliferation. In this context, the coreceptor endoglin plays a key role. It has been observed that endoglin is required to induce efficient ALK1 signaling, which inhibits the ALK5 signaling pathway [7, 20]. These observations suggest that, in prepubertal Leydig cells, TGF- $\beta 1$ acting in concert with progesterone could stimulate proliferation.

Since purified Leydig cells do not proliferate in vitro, we evaluated the in vivo effect of TGF- $\beta 1$ and progesterone on Leydig cell hyperplasia/hypertrophy. Morphometric studies revealed that animals treated with TGF- $\beta 1$ plus progesterone or progesterone alone presented an increment in the volume of the interstitial tissue with a decrease in the tubular compartment volume. Moreover, we observed that in mice treated with TGF- $\beta 1$ and progesterone, Leydig cells showed a decrease in nuclear volume with a concomitant increase in the cytoplasmic volume with respect to the other groups. Together, these results suggest the involvement of TGF- $\beta 1$ and progesterone in Leydig cell hypertrophy. To our knowledge, there are no reports in the literature that have analyzed the in vivo effect of TGF- $\beta 1$ on hypertrophy of Leydig cells. In the present work, the treatment with TGF- $\beta 1$ plus progesterone failed to modify significantly the number of Leydig cells, in spite of a slight increase in this experimental group with respect to the control mice. This result might suggest that prolonged in vivo treatments are required to produce a hyperplasic effect.

In summary, based on the parameters determined in this study, we are prompted to suggest that low doses of TGF- $\beta 1$ in concert with progesterone, are involved in the process of hypertrophy/ 
hyperplasia of Leydig cells. We expect that these results will shed some light on the physiological role of TGF- $\beta 1$ in male reproductive health, since a number of testicular pathologies (Sertoli CellOnly Syndrome, Hypospermatogenesis) in infertile men are associated with hyperplasia and hypertrophy of Leydig cells [22].

\section{Aknowledgment}

This study was supported by grants from the Consejo Nacional de Investigaciones Científicas y Técnicas (CONICET), Agencia Nacional de Promoción Científica y Técnica (ANPCyT) and Facultad de Medicina-Universidad de Buenos Aires.

\section{References}

1. Avallet $\mathbf{O}$, Vigier M, Leduque $\mathbf{P}$, Dubois, PM, Saez JM. Expression and regulation of transforming growth factor-beta 1 messenger ribonucleic acid and protein in cultured porcine Leydig and Sertoli cells. Endocrinology 1994; 134: 2079-2087.

2. Lui WY, Lee WM, Cheng CY. TGF-betas: their role in testicular function and Sertoli cell tight junction dynamics. Int J Androl 2003; 26: 147-160.

3. Ingman WV, Robertson SA. Defining the actions of transforming growth factor beta in reproduction. Bioessays 2002; 24: 904-914.

4. Itman C, Mendis S, Barakat B, Loveland KL. Focus on TGF- $\beta$ signaling. All in the family: TGF- $\beta$ family action in testis development. Reproduction 2006; 132: 233-246.

5. Narula A, Kilen SK, Ma E, Kroeger J, Goldberg E, Woodruff TK. Smad4 overexpression causes germ cell ablation and Leydig cell hyperplasia in transgenic mice. Am J Pathol 2002; 161: 1723-1734.

6. Massagué J, Wotton D. Transcriptional control by TGF- $\beta /$ Smad signaling system. EMBO J 2000; 19: 1745-1754.

7. Lebrin F, Goumans MJ, Jonker L, Carvalho RLC, Valdimarsdottir G, Thorikay M, Mummery C, Arthur HM, ten Dijke P. Endoglin promotes endothelial cell proliferation and TGF- $\beta$ /ALK1 signal transduction. EMBO J 2004; 23: 4018-4028.

8. Kim IY, Kim MM, Kim S-J. Transforming growth factor $\beta$ : Biology and clinical relevance. J Biochem Mol Bio 2005; 38: 1-8.

9. Rulli SB, Ahtiainen P, Mäkelä S, Toppari J, Poutanen M, Huhtaniemi I. Elevated steroidogenesis, defective reproductive organs, and infertility in transgenic male mice overexpressing human chorionic gonadotropin. Endocrinology 2003; 144: 4980-4990.

10. Ahtiainen P, Rulli SB, Shariatmadami R, Pelliniemi LJ, Toppari J, Poutanen M, Huhtaniemi I. Fetal but not adult Leydig cells are susceptible to adenoma formation in response to persistently high level: a study on hCG overexpressing transgenic mice. Oncogene 2005; 24: 7301-7309.

11. Frungieri MB, Mayerhofer A, Zitta K, Pignataro OP, Calandra RS, Gonzalez-Calvar SI. Direct effect of melatonin on Syrian hamster testes: melatonin subtype 1a receptors, inhibition of androgen production, and interaction with the local corticotropinreleasing hormone system. Endocrinology 2005; 146: 1541-1552.

12. Levy H, Deane HW, Rubin BL. Visualization of steroid $3 \beta$-ol-dehydrogenase activity in tissues of intact and hypophysectomized rats. Endocrinology 1959; 65: 932-943.

13. Lowry OH, Rosebrough NJ, Farr AL, Randal RJ. Protein measurement with the Folin phenol reagent. J Biol Chem 1951; 193: 265-275.

14. Leal MC, França LR. The seminiferous epithelium cycle length in the black tufted-ear marmoset (Callithrix penicillata) is similar to humans. Biol Reprod 2006; 74: 616-624.

15. Huang SS, Huang JS. TGF-beta control of cell proliferation. J Cell Biochem 2005; 96 447-462.

16. Lebrin F, Mummery CL. Endoglin-mediated vascular remodeling: mechanisms underlying hereditary hemorrhagic telangiectasia. Trends Cardiovasc Med 2008; 18: 25 32.

17. Gonzalez CR, Gonzalez B, Rulli SB, Huhtaniemi I, Calandra RS, Gonzalez-Calvar SI. TGF- $\beta 1$ system in Leydig cells. Part I: Effect of hCG and progesterone. J Reprod Dev 2010: 56: 389-395

18. Pece-Barbara N, Vera S, Kathirkamathamby K, Liebner S, Di Guglielmo GM, Dejana E, Wrana JL, Letarte M. Endoglin null endothelial cells proliferate faster and are more responsive to transforming growth factor beta1 with higher affinity receptors and an activated Alk1 pathway. J Biol Chem 2005; 280: 27800-27808.

19. Daly AC, Randall RA, Hill CS. Transforming growth factor $\beta$-induced Smad1/5 phosphorylation in epithelial cells is mediated by novel receptor complexes and is essential for anchorage-independent growth. Mol Cell Biol 2008; 22: 6889-6902.

20. Lebrin F, Deckers M, Bertolino P, Ten Dijke P. TGF- $\beta$ receptor function in the endothelium. Cardiovasc Res 2005; 65: 599-608.

21. Goumans MJ, Valdimarsdottir G, Itoh S, Rosendahl A, Sideras P, ten Dijke P. Balancing the activation state of the endothelium via two distinct TGF-beta type I receptors. EMBO J 2002; 21: 1743-1753.

22. Anniballo R, Ubaldi F, Cobellis L, Sorrentino M, Rienzi L, Greco E, Tesarik J. Criteria predicting the absence of spermatozoa in the Sertoli cell-only syndrome can be used to improve success rates of sperm retrieval. Hum Reprod 2000; 15: 2269-2277. 